\title{
DOES CORPORATE GOVERNANCE REALLY \\ PREDICT FIRMS'MARKET VALUES IN EMERGING MARKETS? \\ THE CASE OF RUSSIAN BANKS
}

\author{
Andrei Vernikov ${ }^{1}$ \\ National Research University Higher School of Economics, Moscow; \\ Institute of Economics, Russian Academy of Sciences
}

\begin{abstract}
This paper aims to add to the literature on the connection between corporate governance and company valuation. Conventional wisdom predicts a positive effect of good governance on stock price, and empirical papers claim to have proven this effect for a number of large emerging markets including Russia. We refer to the case of Russian banks to suggest that this connection cannot be established in a convincing way due to data scarcity. A cross-industry panel fails to regard the specificity of financial firms, and a single-industry panel of banks might be unfeasible due to the sheer number of eligible firms. A selection of banks would be biased in favor of publicly listed entities and has little chance of being a wholly representative for the entire industry. Russia's stock market can supply sufficient statistical material for a study involving just two large state-controlled banks. While 20 or so banks maintain some presence in the organized segment of the stock market, over 90 percent of all trading in bank shares and their market capitalization involves the stock of Sberbank and VTB. For them, however, the appropriateness of the market price as the sole comprehensive indicator of performance can be challenged on principle because they have stakeholders who pursue a combination of financial and non-financial goals and assess bank performance differently. The case of Russian banks reveals a critical scarcity of stock market data, so the results of some empirical studies might be attributable to their authors' opinion. This discussion is potentially relevant for other economies that share institutional characteristics such as high ownership concentration, shallowness of the stock market, and substantial role of state-controlled firms.
\end{abstract}

Key words: Russia; banks; corporate governance; valuation; emerging market; stock market

JEL: G21, G34

\section{Introduction}

This paper adds to the literature on the connection between corporate governance (CG) and company valuation. It was motivated by the research papers that explain differences in market performance of companies by the variation in CG level. Stock market presumably accumulates and integrates in the share price all available information including the quality of governance. A well-governed company should cost more than a poorly-run one because good CG reduces risks, and lower risks cut the cost of capital. Conversely, gaps in the capitalization of emerging market companies might stem, among other things, from imperfect CG.

Writings on the governance / performance nexus face challenges such as multi-collinearity between predictor variables featuring CG and the endogeneity of variables on both sides of the model. The direction of the causality between governance and market valuation is an interesting question in its own right: while governance can predict valuation, the reverse can also be true. ${ }^{2}$ Modern econometric techniques can mitigate such problems to some extent; still one must interpret with caution the causality of connections between factors. There are however other issues that are hard to deal with by econometrics alone, namely fundamental scarcity of stock market data. The question mark in the

1. Comments from Vassily Bokov, Alexander Kostyuk and Oleg Shvyrkov are gratefully acknowledged. Thanks also go to Valentina Kuskova, Dmitry Tulin, conference participants at the Ukrainian Academy of Banking (May 2013), and an anonymous language editor at the Higher School of Economics. All the usual disclaimers apply.

2. An expensive company that generates good return to shareholders can afford a comprehensive - and expensive system of CG including a set of highly reputable independent directors, a thorough system of disclosure, an expensive external auditor, a good corporate secretary, etc. A small company in the low-cap segment, conversely, cannot afford all these niceties for purely financial considerations. 
title of this paper reflects a doubt about the feasibility of accurately proving the connection between governance and share price for countries with an underdeveloped stock market incapable of supplying necessary data for computations. It is assumed that a single-industry panel is superior to a crossindustry one because heterogeneity within the sample may conceal different governance models that would cause blurred and inconsistent results.

To illustrate our point we take the case of a particular industry (commercial banking) in a specific emerging market country (Russia), the choice being driven by this author's background and by the fact that Russian banks disclose more information than an average firm in other Russian industries. The focus is on three specific issues: (a) the representativeness of a sample of Russian banks used for empirical studies and the possible selection bias; (b) the capability of the Russian stock market to supply sufficient statistical data; and (c) the appropriateness of market price as performance criterion for the firms in the sample. The hypothesis is that the statistical foundation for would-be empirical studies is weak. A single-industry panel consisting only of eligible commercial banks would be too small. The Russian stock market is too small and shallow to feed a good dataset of bank valuations. There is a liquid market for stocks of two largest state-controlled banks. But for those banks with their peculiar models of governance the market price of equity may be a relatively irrelevant indicator of performance.

Some of the empirical papers on governance - performance correlation in Russia might be making far-fetched conclusions from insufficient evidence, in particular with regard to financial firms. We do not challenge an eventual connection between governance and market performance. The point this paper tries to make is that such a connection should remain a working hypothesis until a stronger statistical basis emerges to document it.

The rest of the text is organized as follows. Section 2 overviews relevant literature. Section 3 addresses the size of the sample and possible selection bias. Section 4 appraises the availability of stock market data reflecting the valuation of Russian banks. Section 5 says a few words about the peculiarity of governance at state-controlled banks. Section 6 concludes.

\section{Literature}

Whether or not indicators of CG can predict the market price of company stock has been tested across countries, with mixed results. In some cases the hypothesis about positive linkage between governance (or rather, governance ratings) and market price finds sufficient statistical proof (Black et al., 2006; Goncharov et al. 2006; Morey et al., 2009), in other cases it does not (Lehn et al., 2007) or it does for selected governance parameters only (Bai et al., 2004; Henry, 2008; Black et al., 2012).

For an analysis of actual governance structures (ownership concentration, Board independence, compensation and procedures, etc.) in Russian listed companies we rely on the survey performed by Deloitte CIS Centre for Corporate Governance (Deloitte, 2012).

Interest in the connection between quality of governance and Russian firm values rose in this century when these firms tapped international capital markets. Black undertook one of the first attempts of a positive study of the correlation between the mechanisms of CG and market valuation of the company stock. The first seminal paper finds the correlation between CG rankings of 21 Russian firms and the "value ratio" of actual market capitalization to potential Western market capitalization for these firms to be striking and statistically strong (Black, 2001).

A subsequent paper broadens the sample from 21 to 99 Russian firms that are publicly floated; extends the period to 1999-2005; uses six CG indices instead of one; introduces additional control variables; and uses a replicable measure of value (Tobin's Q, market/book, and market/sales) instead of a measure of value that depends in part on the judgment of just one investment bank. The authors find an economically important and statistically strong correlation between governance and market value, although it matters a great deal how one measures governance (Black et al., 2006).

Staryuk applies the same conceptual framework to share prices of Russian companies traded in exchanges on-shore and off-shore as ADR/GDR, with market capitalization as dependent variable 
(Staryuk, 2008). One of explanatory variables groups relates to CG and includes Board functioning; motivation and decision-making; internal and external audit; transparency; and investor relations. It is found that publication of IFRS reports is a good sign and that generous dividend policy enhances market capitalization. There is however insufficient statistical proof that internal mechanisms of CG increase shareholder value.

Bokov and Vernikov focus specifically on Russian banks in the search for factors that investors deem significant in making a decision whether to invest in a given firm and, if yes, at what price. The sample contains a mix of takeover deals by foreign strategic investors and public offerings of bank stock. Price-to-book-value of equity (P/BV) multiple is used as measurement of valuation and the dependent variable. External investors seem to attach value to high concentration of ownership, size of the bank, stability of the governing bodies, and involvement of well-established external auditors. Strategic investors tend to pay higher acquisition premiums than portfolio investors. The features of the Board of Directors such as its independence, maturity and stability appear to create less value if any (Bokov, Vernikov, 2008).

Shvyrkov and Pastoukhova research the connection between CG and stock market valuation for 46 public companies in Russia and Kazakhstan (Standard \& Poor's, 2010). The study finds a statistically significant and practically meaningful predictive power of the historical CG scores for medium-term financial performance and growth in market capitalization. A one-notch positive difference on S\&P's governance scoring scale corresponded, on average, to an additional 5.2 percent in annualized sales growth and 7.0 percent in annualized market cap growth over a three-year horizon. Predictive power of governance in terms of shareholder value exceeds its perception by financial markets. CG ratings included all those assigned by the agency and not only the public ones.

In a study of value-based management Ivashkovskaya analyzes the key factors driving economic profit of Russian companies. Her model suggests that for a sample of 26 Russian companies from 2002 through 2007 there was direct statistical dependence of economic profit from transparency and disclosure scores as assigned by Standard \& Poor's (Ivashkovskaya, 2010).

Bokov and Vernikov build a censored panel with 70 observations for 24 commercial banks, both listed and unlisted ones, over 2007-2009. Market capitalization is replaced by $P / B V$ multiples where $P$ is computed via discounted cash flows method. CG level is expressed through a self-devised index for all firms in the sample. The econometric result is that during a financial crisis when prices fall across the board the correlation between governance and price becomes weaker; external investors appear unlikely to reward CG improvements with their money. This result might reflect the specificity of the chosen period of observations (Bokov, Vernikov, 2011).

Black, de Carvalho and Gorga undertake a multi-country study comparing Brazil to Russia, India and Korea. They find mixed evidence of the effects of governance on Tobin's Q. The authors suggest that "good" governance practices are not universal (one size mostly fits all) and depend on country and firm characteristics, thus advocating for a flexible approach to governance, with ample room for firm choice (Black et al., 2012).

Equity analysts from Aton brokerage apply to 111 Russian stocks a system of governance scoring (CGS) influenced by the Standard \& Poor's GAMMA index. The governance indicator happens to affect strongly and positively the stocks' performance and reduce the non-financial risk of investments (Aton, 2012).

Stepanova and Ivantsova check whether CG had an effect on stock market performance of 150 banks from 27 European countries and report a positive connection with ownership concentration, state ownership and Board independence (Stepanova, Ivantsova, 2012).

Lastly, the members of Sberbank Investment Research categorize CG events over the past decade for Russia's 55 most liquid companies into 12 quantifiable corporate governance factors and then analyze these against each company and sector's subsequent share price performance. An abuse of minority investors might de-rate the market price by an average of up to 50 percent in 12 months. 
Other governance factors often thought important by investors, such as changes in the Board of Directors and management, news on privatization and the adoption of IFRS accounts, have little impact on share price performance (Sberbank CIB, 2013).

\section{Sample representativeness and selection bias}

Statistical analysis of governance - market performance correlation requires a certain number of firms meeting criteria such as availability of financial statements (Russian Accounting Standards and/or IFRS) and non-financial information; possession of an S\&P Corporate Governance score, GAMMA score, S\&P Transparency and Disclosure index or a similar score from an external provider; and stock in public float in a major stock exchange in Russia or abroad.

Selection is unavoidably biased in favour of entities that make data publicly available. This condition seems trivial, but not so in Russia. Building a database on Russian banks takes a lot of field work (Schoors, 2000). In 2009 only 14 out of top 50 banks were disclosing all three main forms of reporting - accounts based on Russian Accounting Standards, quarterly reports of securities issuer, and IFRS / GAAP financial reports (Bokov, 2010). A substantial proportion of information reported by Russian banks is available to the regulator only but not general public.

Black recognizes in his first paper on Russia that results are tentative because the sample of 21 firms is too small (Black, 2001), so his subsequent paper broadens the sample to 99 Russian firms (Black et al., 2006). Shvyrkov and Pastoukhova research 46 companies in Russia and Kazakhstan (Standard \& Poor's, 2010). Ivashkovskaya analyzes 26 large Russian companies [Ivashkovskaya, 2010]. Deloitte experts look at 135 corporations (Deloitte, 2012). All these are cross-industry panels. A cross-industry panel is heterogeneous and some sectors are more heavily represented than others. Communications, utilities and extraction sectors represent 77 percent of the sample built by (Black et al., 2006). In the study by Deloitte, 70 percent of the sample is made up by electrical power utilities (34 firms), industrial metals and mining (23 firms) and oil and gas producers (13 firms) (Deloitte, 2012, p.7).

A cross-sector panel may turn in results hard to interpret because different sectors and industries use rather distinct models of governance due to varying size, ownership concentration, regulation, market shares, business models, etc. The sign of the result may change from one sector to another: what works for an FMCG company or an airline may not work for a bank. A study of 4 large emerging markets confirms that firm characteristics do matter: governance predicts market value for nonmanufacturing (but not manufacturing) firms, small (but not large) firms, and high-growth (but not low-growth) firms (Black et al., 2012). Not least, policy implications based on a crossindustry panel analysis can be misguided because regulation of financial firms is rather special. Empirical findings for a sample shifted towards mining, utility, energy etc. companies have limited value for a bank regulator. It therefore matters whether banks are sufficiently represented in the datasets before one can extrapolate the empirical findings to the entire Russian banking industry. The exact composition of the dataset and its breakdown by industry are surprisingly rarely disclosed in empirical papers. Russian banks are covered quite modestly, their number is usually a single digit figure (Table 1). In cases where authors do not provide a breakdown of the sample the number of banks is unlikely to be much higher anyway. Just to remind that according to CBR there were 894 active banks in Russia on July 1, 2013.

Table 1

Coverage of banks in empirical studies of corporate governance in Russia

\begin{tabular}{cccc}
\hline Study & Single industry or Cross-industry & Number of firms in the panel & of which Russian banks \\
\hline Black (2001) & C & 21 & $?$ \\
$\begin{array}{c}\text { Black, Love, Rachinsky } \\
\text { (2006) }\end{array}$ & C & 99 & $?$ \\
Bokov, Vernikov (2008) & S & 10 & 10 \\
Morey et al. (2009) & C & $19 *$ & $?$
\end{tabular}




$\begin{array}{cccc}\text { Standard \& Poor's (2010b) } & \text { C } & 46 & ? \\ \text { Ivashkovskaya (2010) } & \text { C } & 26 & ? \\ \text { Bokov, Vernikov (2011) } & \text { S } & 24 & 24 \\ \text { Black, de Carvalho, Gorga } & \text { C } & 99 & 5 \\ \quad(2012) & \text { C } & 111 & 6 \\ \text { Aton (2012) } & \text { C } & 135 & ? \\ \text { Deloitte (2012) } & \text { S } & 150 & 3 \\ \text { Stepanova, Ivantsova } & \text { C } 2012) & 55 & * \text { Russia only }\end{array}$

Research seldom covers privately held unlisted firms, and that is unfair because CG improvement often precedes a public offering of shares. Omission of companies in earlier stages of their life cycle hides the dynamic effects of governance on company value. Bokov and Vernikov (2011) do include unlisted banks in the sample, even if at the risk of inconsistency in the data. Their method of obtaining valuation multiples from actual transactions involving acquisition of control by foreign strategic investors yields data of fine quality but the number of observations is too small. The authors identify 23 eligible transactions involving Russian banks within 2004-2008, and not all of them are suitable for quantitative research.

Another possible bias rests in the selection of companies and banks that have been assigned an S\&P corporate governance score, GAMMA score or a similar index by a reputable external party. Each issuer of governance ratings awards them to a limited number of Russian firms. ${ }^{1}$ Self-selection of clients takes place because normally only relatively large companies and those expecting to obtain an acceptable CG rating request it. Commercial providers (investment banks etc.) who assign governance scores to their own paying clients can have a conflict of interest likely to result in upward bias. Anyhow banks with a CG score make up a very small sample. Just 2 or 3 banks had a corporate governance score from S\&P, and none had a GAMMA score. The composition of the index (and therefore its meanings) is biased towards non-financial firms or misses banks altogether.

The scarcity of externally-assigned governance scores prompts using transparency and disclosure scores assigned by Standard \& Poor's - S\&P T\&D - as a proxy of CG quality. The provider explicitly warns against doing that because in the study of transparency and disclosure only publicly-available information is used, which invalidates any comparison of T\&D scores with CG ratings (CGR and GAMMA) or their interpretation as an integral indicator of governance quality [Standard \& Poor's, 2008 b, p.6]. The use of T\&D does not greatly expand the range of banks: only 3 banks are among 90 Russian companies awarded a T\&D score.

\section{Availability of data to assess stock market performance of banks}

Authors often use as the dependent variable the market performance of company stocks (Black, 2001; Black et al., 2006; Staryuk, 2008; Morey et al., 2009; Stepanova, Ivantsova, 2012) or a derivative thereof, such as valuation multiples or "private benefits of control". ${ }^{2}$ It places the focus on public companies with stocks in free float. These are scarce. Russian companies rely less on stock market for capital financing. On average Russian public companies have 28 percent of free float (Deloitte, 2012) which might be an optimistic estimate. Out of 100 largest banks that control 89.4 percent of total assets, 62 institutions with 84.6 percent of all assets are "OAO" (open joint-stock companies),

1. Black, Love and Rachinsky (2006) address the scarcity of CG scores from one provider as follows. They take 6 indices produced by 6 agencies, convert them to a standard normal distribution to make the indices comparable, and then put them together to produce a combined index of governance in Russian firms. This technique offers a working solution but, in part, different indices cover different companies at different times. Standard \& Poor's study (2010) covers 46 companies in Russia and Kazakhstan with a CG score from S\&P.

2. Muravyev, Berezinets and Ilina compute private benefits of control (PBC), i.e. the difference between ordinary and preferred stock prices for a sample of dual class stock companies traded on the Russian stock exchange. The result for PBC is stronger than for traditional measures of CG (Muravyev et al., 2012). The approach is interesting, but hardly applicable in our case where only two Russian banks (Sberbank and Vozrozhdenie) have floated both common and preferred stock (Annex 1). 
26 are "ZAO" (closed joint-stock companies) and 12 are "OOO" (limited liability companies). OAO, however, is not an equivalent of a publicly listed company. The majority of the OAOs are either unlisted or have no free float, and sometimes have just one core owner.

As far as banks are concerned, Peresetsky argued that in the early 2000s the analysis of price dynamics of bank shares could not underpin off-site statistical modelling and assessment of bank stability in view of the sheer number of floating banks in Russia (Peresetsky, 2012) Since then not much has changed. A small minority of Russia's 900 banks are listed in stock markets in Russia or abroad. Just 20 banks have stocks registered in the Moscow Exchange in one of the quotation lists; of which 3 banks appear in List A in the $1^{\text {st }}$ tier and one bank in the $2^{\text {nd }}$ tier (see Annex 1). Listings on foreign stock exchanges do not add much to the sample.

A sample of floating Russian banks looks comfortably representative in terms of its share of total assets. At the same time, in terms of market liquidity there is very high concentration on just three instruments issued by two state-controlled banks. On randomly chosen trading days (June 3, 2013 and September 30,2013) over 80 percent of the total volume of trade in bank shares in the Moscow Exchange were in Sberbank shares, another 19 percent or so in VTB shares, leaving less than 1 percent for all other bank issuers (see Fig.1 and Annex 1).

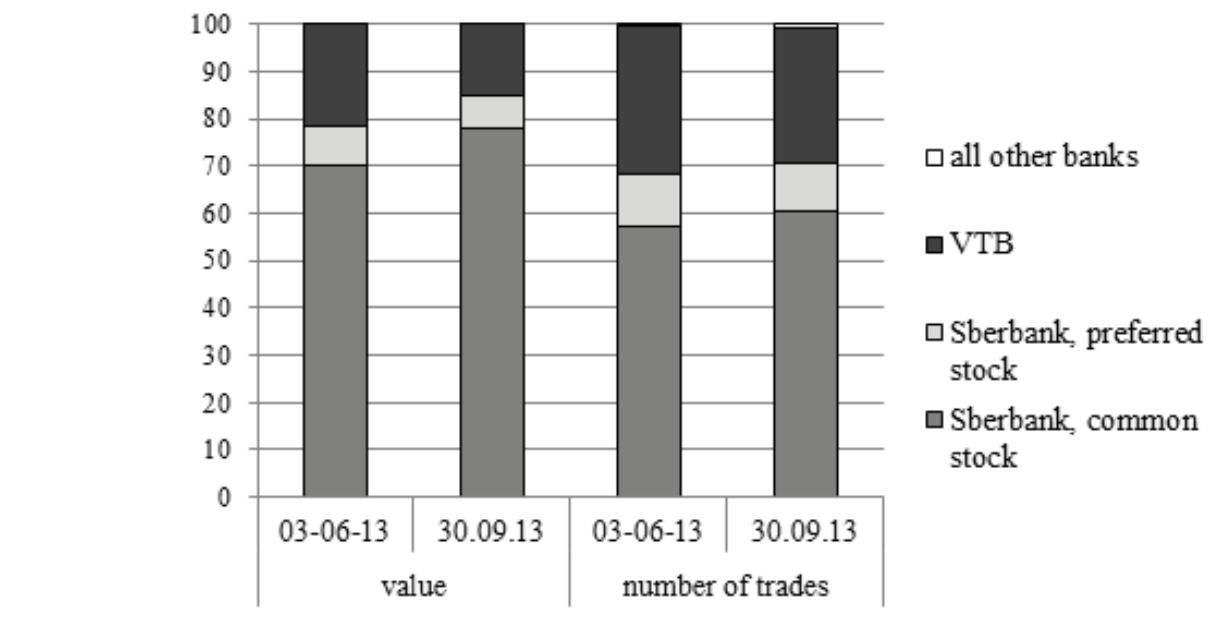

Source: own calculation based on MICEX, http://www.micex.ru/infocenter/researches/bulletins/

Figure 1: Trading in Russian bank shares in the Moscow Exchange

(averages of two randomly chosen trading days, June 3, 2013 and September 30, 2013)

The concentration is equally high in terms of market capitalization. The combined capitalization of the 5 banks covered in the Aton survey is USD 79.3bn, out of which USD 76.4bn or 96 percent is Sberbank and VTB, while Nomos Bank, Vozrozhdenie and Bank Sankt-Peterburg together hold less than 4 percent (Aton, 2012).

The stock market can thus supply statistical data to construct time series of market prices for Sberbank and $V T B$ but hardly any other Russian bank. There was some turnover in shares of 8 other banks ( 0.28 percent of the number of trades and 0.03 percent of total volume) while others remained completely illiquid. Domestic private and foreign-controlled banks are grossly underrepresented (among the latter, only Rosbank / Société Générale is a public corporation). A bank stock being included in the quotation list A1 (presumably "blue chips") does not guarantee liquidity as the case of Nomos Bank shares shows. Indicative quotes in the trading system and several daily trades may reflect the activity of appointed market makers but not genuine liquidity. Missing market data in a panel can push a scholar to recur to questionable techniques. ${ }^{1}$ Importantly also, the average performance of banking sector stocks becomes strongly driven by stock performance of Sberbank and $V T B$. The sector average indicator is widely used for benchmarking. The stock performance of a privately-owned Russian bank - e.g., Bank Sankt-Peterburg as in the study by Sberbank Investment Research (Sberbank CIB, 2013) - is thus measured against that of two large state-controlled banks but not that of comparable peer banks.

1. If a firm does not trade in a particular quarter, Black et al. (2006) interpolate market value of its equity based on the prior and subsequent quarters. 
Empirical findings based on Russian stock market data should not be generalized for the entire industry. Whether this situation is likely to change in the foreseeable future depends largely on the prospects of the stock market. Over 2011-12 the main indicators of the Russian equity market stagnated or went into decline, its share in the country's GDP fell and so did the number of active market participants (Yakovenko, 2013). One of the reasons why Russian companies and banks are less interested in stock market scrutiny relates to the dominant ownership structure, namely high concentration of influence and ownership ${ }^{1}$ (Vernikov, 2007). Practically none of Russian banks can be described as a public widely-held corporation; there is always one party in charge of key decisions. Minority shareholders, including the founders of the company or its strategic investors, are aligned with the blockholder and likely to coordinate their votes on essential issues even in the absence of an explicit shareholder agreement. There may also be no minority shareholders at all, like in Rosselkhozbank.

\section{Relevance of market price for state-controlled banks}

As mentioned above, stock market activity is almost entirely driven by the shares of two "national champions" (Sberbank and VTB). The leadership of state-controlled banks in the stock market is consistent with their market position overall. The combined market share of 35 state-controlled banks that this author could identify is approximately 59 percent (Fig.2). ${ }^{2}$ Banks from this category held the first six positions of the national ranking assets-wise by 2013.

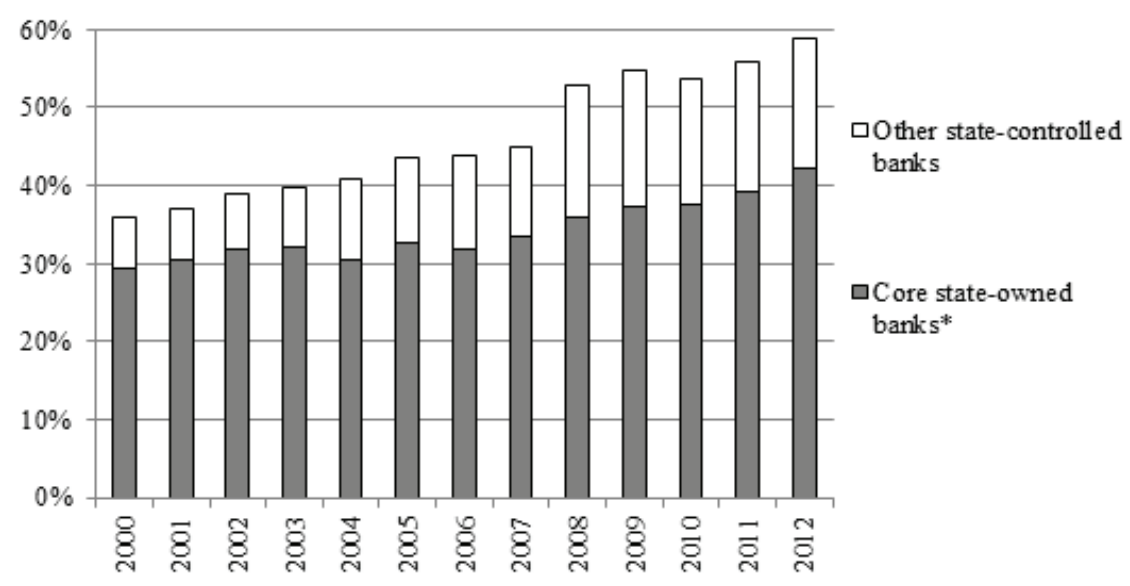

* Sberbank, Bank VTB and Rosselkhozbank, without subsidiaries

Source: Author's calculations based on bank data (Vernikov, 2013); http://rating.rbc.ru/category.shtml?banks

Figure 2: Market share of state-controlled banks (percent of total banking assets at year end)

There is a wide gap between Sberbank and $V T B$, on the one hand, and the rest of the public Russian banks, on the other. These institutions are systemically important and by far "too big to fail". The level of sovereign support to them is factored into their credit ratings. Only state-controlled banks in Russia have investment-grade credit ratings from Moody's and Standard \& Poor's, whereas none of the privately-held banks has such a rating. As a result the state-controlled banks have the lowest cost of funding that creates a huge competitive edge over all other market participants. Size also matters

1. 91 percent of all Russian public companies surveyed by Deloitte had at least one block holding exceeding 25 percent, and 60 percent of the companies in the sample had a single ultimate majority shareholder. The average size of the largest block holding is 50 percent (Deloitte, 2012b).

2. By recognizing state ownership only on stakes owned by a federal executive body the official statistics understates the amount of property under state control. CBR reports for state-controlled banks a market share of 50.4 percent by the end of 2012 (CBR, 2013), which is 8.4 percentage points lower than the figure resulting from my alternative method of identifying state-controlled banks (Vernikov, 2013). That method embraces some additional types of banks, e.g. those controlled by state-owned industrial companies. Recalculation was caused by superficial formal disclosure of ownership form and structure, in particular with regard to public property (Vernikov, 2012). According to official disclosure of Sberbank, only 0.029 percent of its equity belongs to the state, whereas the correct figure should be 52.32 percent if we count the stake of the Central Bank of Russia. 
for CG because only a large enough entity can afford fully-fledged mechanisms of CG. This has an effect on market valuation.

Another factor potentially affecting stock market valuation is financial efficiency. Despite the fact that in Russia state-controlled banks pursue both financial and non-financial objectives, they lead in terms of most commonly used indicators of financial performance (Annex 2). That contradicts theoretical literature on state ownership and economics of transition that believe state-owned banks to lag behind in terms of efficiency. Karas, Schoors and Weill were among the first to identify this phenomenon (Karas et al., 2010) that requires interpretation and additional research. Before we fully understand the reasons behind this anomaly, financial performance - and therefore market performance - of core state-controlled might be incomparable in a direct fashion with that of ordinary commercial banks that perform a traditional set of functions. The governance model of the main state-controlled banks is geared towards a different range of stakeholders and their relative weight. In line with the "development theory" of government banking, government participation in the equity of banks is meant to offset the weakness of domestic private capital and its unwillingness to finance infrastructural or industrial projects. At the same time governments employ public sector banks to promote a political agenda (La Porta et al., 2002). Russia's state-controlled banks can execute non-commercial functions on behalf of the authorities, e.g. support liquidity levels in the national economy and stabilize output during cyclical downturns (Fungáčová, Weill, 2012) or spearhead outward expansion of the Russian state capital in pursuit of foreign policy goals. These banks play a special role in the economy and make up a separate tier of the Russian banking system (Vernikov, 2013); they combine regular banking activity with policy lending. Apart from standard loans the balance sheets of Russia's three "national champions" contain a sizeable proportion of politically motivated assets, such as shares of "strategically-important" companies, subsidized loans to certain categories of borrowers or loans subscribed under targeted government programs, investments in high-profile infrastructural and entertainment projects and real estate. In view of the above-mentioned reasons, the performance of core state-controlled banks cannot be reduced to the dynamics of financial indicators or share price.

One can nevertheless spot a significant difference in the stock performance of two leading Russian banks (Annex 3). Whether the misalignment is driven by factors related to the governance model of Sberbank and VTB could become the subject of a multiple case study.

\section{Conclusion}

Conventional wisdom and theoretical literature predict a positive connection between CG and company valuation, and some authors claim to have proven this effect for large emerging market countries including Russia. In these papers panel regressions tend to be run on relatively small samples. With few exceptions, those are cross-industry panels that mingle financial firms with resource companies, utilities, etc. But firm characteristics matter for the optimal model of governance (Black et al., 2012). From a bank regulator's perspective the results obtained from a heterogeneous panel are essentially useless due to the specificity of financial firms whereas evidence from empirical studies driven by oil \& gas companies and utilities has limited relevance. A single-industry panel, however, may be unfeasible due to the scarcity of eligible firms. The selection of Russian commercial banks would be biased in favor of large publicly listed entities and those with an externally assigned governance score.

A study of the impact of something on market prices might require those market prices, in the first place. Only 20 or so banks have their shares registered on the Moscow Exchange and maintain a nominal presence in the organized segment of the stock market; for some of them there can be no transactions at all during a randomly chosen trading day. Market valuation becomes an abstract concept in the absence of a liquid market for the given instrument. Over 90 percent of all trading in bank shares relates to those of Sberbank and VTB. Russia's stock market can therefore supply sufficient statistical material for an empirical study involving those two large state-controlled banks, but results do not necessarily apply to the entire banking industry. 
For the two state-controlled banks the appropriateness of market price as the sole comprehensive indicator of performance can be challenged on principle. Unlike the shareholders of privately owned banks that maximize share price, the main stakeholders of state-controlled banks might expect a different set of outputs and thus assess bank performance differently. "National champions" play a special role in the banking system and the economy and pursue a combination of financial and nonfinancial goals. This consideration may cast doubt on the results from the analysis of a banking panel across several countries, as in other countries the featured banks are likely to have a different form of ownership than in Russia.

This paper implies that governance is relevant for market performance although the effect is hard to document in an emerging market like Russia and especially across firms in the same industry. We do not try challenging some author's regression model by another model as there may be little to model in general. Perhaps time has yet to come for this research. The situation might change if and when a greater number of Russian commercial banks get listed, although such a prospect appears rather remote. In the meantime the unreliability of the response variable compromises the computations of governance impact on market valuation. The case of Russian banks reveals a critical scarcity of stock market data, something that even advanced statistical techniques cannot deal with unless one starts making bold assumptions or interpolating data. Positive bias in the process of proving the importance of governance for equity price might stem from the fact that a large proportion of scholarly papers are actually sponsored by consultancies, brokerages, rating agencies, audit firms, business associations and alike actors many of whom happen to offer [paid] services in the area of CG.

These deliberations might bear relevance for other economies that share institutional characteristics such as high ownership concentration, shallowness of the stock market, and substantial role of statecontrolled firms.

\section{References}

1. Bai C.-E., Liu Q., Lu J., Song F., Zhang J. Corporate governance and market valuation in China. Journal of Comparative Economics, 2004, 32(4), pp. 599-616.

2. Black B. The corporate governance behavior and market value of Russian firms. Emerging Markets Review, 2001, 2(2), pp. 89-108.

3. Black B., De Carvalho A., Gorga E. What matters and for which firms for corporate governance in emerging markets? Evidence from Brazil (and other BRIK countries). Journal of Corporate Finance, 2012, 18(4), pp. 934-952.

4. Black B., Jang H., Woochan, K. Does corporate governance predict firms' market values? Evidence from Korea. Journal of Law, Economics, and Organization, 2006, 22(2), pp. 366413.

5. Black B., Love I., Rachinsky A. Corporate governance indices and firms' market values: Time series evidence from Russia. Emerging Markets Review, 2006, 7(4), pp. 361-379.

6. Bokov V., Vernikov A. Interplay between corporate governance and market value of Russian banks: Are investors prepared to reward governance quality? National Corporate Governance Report, 2011, Issue 4, NCGC (Moscow), pp. 52-80.

7. Bokov V., Vernikov A. Possible impact of corporate governance profile on a Russian bank valuation. Economics Working Paper No.95, CSESCE, UCL School of Slavonic and East European Studies (L.), 2008.

8. Bokov V.A. Problemy formirovaniia massivov dannykh dlia empiricheskogo analiza bankovskogo sektora [Problems of databases formation for empirical analysis of banking sector]. Voprosy statistiki [Statistical issues], 2010, № 4, pp. 52-56.

9. $C B R$ (2011). Review of the banking sector of the Russian Federation, 2010. Moscow, Russia, Central Bank of the Russian Federation and Novosti Press. 
10. CBR (2013). Review of the banking sector of the Russian Federation, 2012. Moscow, Russia, Central Bank of the Russian Federation and Novosti Press.

11. Coles J., Daniel N., Naveen L. Boards: Does one size fit all? Journal of Financial Economics, 2008, 87(2), pp. 329-356.

12. Corporate Governance Structures of Public Russian Companies. Moscow, 2012, Deloitte CIS Centre for Corporate Governance. Available at: www.corpgov.deloitte.ru

13. Corporate Governance: Faulty Powers. ATON Equity Research, July 9, 2012. Available at: http://www.atonbroker.com/en/research (accessed 22 July 2013).

14. FungáčováZ., Weill L. Bank liquidity creation in Russia. Eurasian Geography and Economics, 2012, 53(2), pp. 286-300.

15. Goncharov I., Werner J., Zimmermann J. Does compliance with the German corporate governance code have an impact on stock valuation? An empirical analysis. Corporate Governance: An International Review, 2006, 14(5), pp. 432-445.

16. Gross S. Banks and Shareholder Value: An Overview of Bank Valuation and Empirical Evidence on Shareholder Value for Banks. PhD dissertation. Wiesbaden, DUV, 2006.

17. Henry D. Corporate governance structure and the valuation of Australian firms: Is there value in ticking the boxes? Journal of Business Finance \& Accounting, 2008, 35(7-8), pp. 912-942.

18. Iakovenko D. My pochti poteriali ego [We have almost lost it]. Ekspert [Expert], 2013, № 22(853), pp. 38-40.

19. Ivashkovskaia I.V. Sistema integrirovannogo upravleniia stoimost'iu kompanii. Avtoref. dis. ... d-ra ekonom. nauk po spetsial'nosti 08.00.05 i 08.00.10 [System of integrated management of corporate value. Dr. econ. sci. diss. abstract]. Moscow, State University HSE, 2010.

20. Karas A., Schoors K., Weill L. Are private banks more efficient than public banks?: Evidence from Russia. Economics of Transition, 2010, 18(1), pp. 209-244.

21. La Porta R., López-de-Silanes F., Shleifer A. Government ownership of banks. Journal of Finance, 2002, 57 (1), pp. 265-301.

22. Lehn K., Patro S., Zhao Mengxin Governance indexes and valuation: Which causes which? Journal of Corporate Finance, 2007, 13(5), pp. 907-928.

23. Levine R. The corporate governance of banks: A concise discussion of concepts and evidence. World Bank Policy Research Working Paper, No. 3404, 2004.

24. Morey M., Gottesman A., Baker E., Godridge B. Does better corporate governance result in higher valuations in emerging markets? Another examination using a new data set. Journal of Banking \& Finance, 2009, 33(2), pp. 254-262.

25. Muravyev A., Berezinets I., Ilina Y. CEO and Board characteristics as determinants of private benefits of control: Evidence from the Russian Stock Exchange. IZA Discussion Paper, No. 6256, 2012.

26. Peresetskii A.A. Ekonometricheskie metody $\mathrm{v}$ distantsionnom analize deiatel'nosti rossiiskikh bankov [Econometric methods in distant analysis of activities of Russian banks]. Moscow, Publishing house of the Higher School of Economics, 2012.

27. Russian corporate governance - Embracing the opportunity. Sberbank Investment Research, Sberbank CIB (2013). Available at: http://sberbank-cib.ru/rus/about/news/sberbank_cib_ news/index.wbp?number=1889 (accessed 22 July 2013).

28. Schleifer A., Vishny R. A survey of corporate governance. Journal of Finance, 1996, 52 (2), pp. 757-783.

29. Schoors K. A note on building a database on Russian banks: Fieldwork against the odds. Post-Communist Economies, 2000, 12 (2), pp. 241-249. 
30. Stariuk P.Iu. Vliianie korporativnogo upravleniia na stoimost' rossiiskikh kompanii (empiricheskii analiz). Avtoref. dis. ... kand. ekonom. nauk [Influence of corporate governance on the value of Russian companies (empirical analysis). Cand. econ. sci. diss. abstract]. Moscow, State University HSE, 2008.

31. Stepanova A., Ivantsova O. Does corporate governance have an effect on performance in the European banking sector? Evidence from a crisis environment. Higher School of Economics Research Paper No. WP BRP 10/FE/2012.

32. Study of information transparency of Russian companies in 2008: Modest progress against the background of deep fall in number of IPOs. Joint study of Standard \& Poor's and CEFIR. S\&P, Moscow, 2008.

33. The governance Alpha: Back-testing the correlations of S\&P's governance scores with corporate performance (Russia and Kazakhstan, 2000-2009). Standard \& Poor's, 2010.

34. Vernikov A. Corporate governance and control in Russian banks. Economics Working Paper No.78, CSESCE, UCL School of Slavonic and East European Studies, L., 2007.

35. Vernikov A. State-controlled «national champions» of the Russian banking market: Concentration, competitiveness and efficiency. SSRN Working Paper Series No. 2223686, 2013. 
Annex 1

Vernikov A. The impact of state-controlled banks on the Russian banking sector, Eurasian Geography and Economics, 2012, 53(2), pp. 250-266.

Table 2

\section{Russian bank shares registered in the Moscow Exchange}

(trading results on two randomly chosen days, June 3, 2013 and September 30, 2013)

\begin{tabular}{|c|c|c|c|c|c|c|c|c|}
\hline \multirow{2}{*}{$\begin{array}{l}\text { Listing } \\
\text { type* }\end{array}$} & \multirow{2}{*}{ Issuing bank name } & \multirow{2}{*}{$\begin{array}{l}\text { Stock } \\
\text { type** }\end{array}$} & \multicolumn{3}{|c|}{$\begin{array}{l}\text { Value of trading, } \\
\text { RUB mln**** }\end{array}$} & \multicolumn{3}{|c|}{ Number of trades } \\
\hline & & & 03.06 .13 & 30.09 .13 & Avrg & 03.06 .13 & 30.09 .13 & Avrg \\
\hline A1 & Sberbank & $\mathrm{C}$ & $10,112.0$ & $6,942.5$ & $8,527.3$ & 76,498 & 34,867 & 55,683 \\
\hline A1 & VTB & $\mathrm{C}$ & $3,077.2$ & $1,351.1$ & $2,214.2$ & 41,708 & 16,504 & 29,106 \\
\hline A1 & Sberbank & $\mathrm{P}$ & $1,221.7$ & 586.6 & 904.2 & 14,610 & 5,936 & 10,273 \\
\hline A1 & Nomos Bank & $\mathrm{C}$ & 0 & 8.2 & 4.1 & 0 & 10 & 5 \\
\hline A1 & Vozrozhdenie & $\mathrm{C}$ & 0.4 & 0.5 & 0.5 & 96 & 149 & 123 \\
\hline $\mathrm{B}$ & Bank S.-Peterburg & $\mathrm{C}$ & 1.3 & 4.1 & 2.7 & 219 & 197 & 208 \\
\hline $\mathrm{B}$ & Rosbank & $\mathrm{C}$ & 0.0 & 0.0 & 0.0 & 31 & 7 & 19 \\
\hline $\mathrm{V}$ & Mosoblbank & $\mathrm{C}$ & 3.1 & 0.7 & 1.9 & 9 & 11 & 10 \\
\hline $\mathrm{V}$ & Vozrozhdenie & $\mathrm{P}$ & 0.0 & 0.0 & 0.0 & 4 & 9 & 7 \\
\hline $\mathrm{V}$ & Bank Moskvy & $\mathrm{C}$ & 0.0 & 0.0 & 0.0 & 5 & 4 & 5 \\
\hline $\mathrm{V}$ & Uralsib & $\mathrm{C}$ & 0.0 & 0.0 & 0.0 & 5 & 12 & 9 \\
\hline $\mathrm{V}$ & RegBR & $\mathrm{C}$ & 0.0 & 0.0 & 0.0 & 3 & 1 & 2 \\
\hline $\mathrm{V}$ & Kuznetsky & $\mathrm{C}$ & 0 & 0.0 & 0.0 & 0 & 2 & 1 \\
\hline V & Yaroslavich & $\mathrm{C}$ & 0.0 & 0 & 0.0 & 2 & 0 & 1 \\
\hline $\mathrm{V}$ & KIT Finance & $\mathrm{C}$ & 0 & 0 & 0 & 0 & 0 & 0 \\
\hline $\mathrm{V}$ & Avangard & $\mathrm{C}$ & 0 & 0 & 0 & 0 & 0 & 0 \\
\hline $\mathrm{V}$ & Primorye & $\mathrm{C}$ & 0 & 0 & 0 & 0 & 0 & 0 \\
\hline $\mathrm{V}$ & Tavricheskiy & $\mathrm{C}$ & 0 & 0 & 0 & 0 & 0 & 0 \\
\hline $\mathrm{V}$ & TransKreditBank & $\mathrm{C}$ & 0 & 0 & 0 & 0 & 0 & 0 \\
\hline $\mathrm{V}$ & Petrokommerts - 1 & $\mathrm{C}$ & 0 & 0 & 0 & 0 & 0 & 0 \\
\hline V & Petrokommerts -2 & $\mathrm{C}$ & 0 & 0 & 0 & 0 & 0 & 0 \\
\hline V & Petrokommerts -3 & $\mathrm{C}$ & 0 & 0 & 0 & 0 & 0 & 0 \\
\hline $\mathrm{V}$ & Petrokommerts -4 & $\mathrm{C}$ & 0 & 0 & 0 & 0 & 0 & 0 \\
\hline $\mathrm{V}$ & Petrokommerts -5 & $\mathrm{C}$ & 0 & 0 & 0 & 0 & 0 & 0 \\
\hline V & Petrokommerts -6 & $\mathrm{C}$ & 0 & 0 & 0 & 0 & 0 & 0 \\
\hline $\mathrm{V}$ & Alor Bank & $\mathrm{C}$ & 0 & 0 & 0 & 0 & 0 & 0 \\
\hline $\mathrm{V}$ & Promsvyazbank & $\mathrm{C}$ & 0 & 0 & 0 & 0 & 0 & 0 \\
\hline & Total & & 14,416 & 8,894 & 11,655 & 133,190 & 57,709 & 95,450 \\
\hline
\end{tabular}

* A1 - List A, first level; B - List B; V - non-listed security. ** - C - common stock; P - preferred stock.

*** - "0" means no trading, "0.0" means daily amount of trading lesser than RUB 100,000.

Source: MICEX, http://rts.micex.ru/a1600 ; http://www.micex.ru/infocenter/researches/bulletins

Annex 2

Table 3

Financial performance of Russian banks

\begin{tabular}{|l|l|l|l|l|l|l|l|l|}
\hline \multirow{2}{*}{} & \multicolumn{4}{|c|}{ Return on assets (ROA) } & \multicolumn{4}{c|}{ Return on equity (ROE) } \\
\cline { 2 - 9 } & 2009 & 2010 & 2011 & 2012 & 2009 & 2010 & 2011 & 2012 \\
\hline
\end{tabular}




\begin{tabular}{|c|c|c|c|c|c|c|c|c|}
\hline All banks & 0.7 & 1.9 & 2.4 & 2.3 & 4.9 & 12.5 & 17.6 & 18.2 \\
\hline State-controlled banks* & 0.7 & 2.4 & 2.8 & 2.5 & 4.3 & 14.8 & 20.6 & 20.1 \\
\hline Foreign-controlled banks & 1.1 & 2.1 & 2.4 & 2.5 & 8.3 & 14.5 & 17.4 & 18.8 \\
\hline Large private banks & 0.4 & 1.1 & 1.7 & 1.9 & 3.2 & 8.4 & 14.2 & 16.0 \\
\hline $\begin{array}{l}\text { Small and medium-sized banks, Moscow } \\
\text { region }\end{array}$ & 1.2 & 1.4 & 1.5 & 1.5 & 5.2 & 6.7 & 8.0 & 8.5 \\
\hline $\begin{array}{l}\text { Small and medium-sized banks, other } \\
\text { regions }\end{array}$ & 1.1 & 1.5 & 1.7 & 1.7 & 6.2 & 9.8 & 10.4 & 10.7 \\
\hline
\end{tabular}

* CBR definition of state-controlled banks; embraces banks directly controlled by the government and/or "state corporations"

Sources: CBR, 2011, p.25-26; CBR, 2013, p. 32-33.

Annex 3
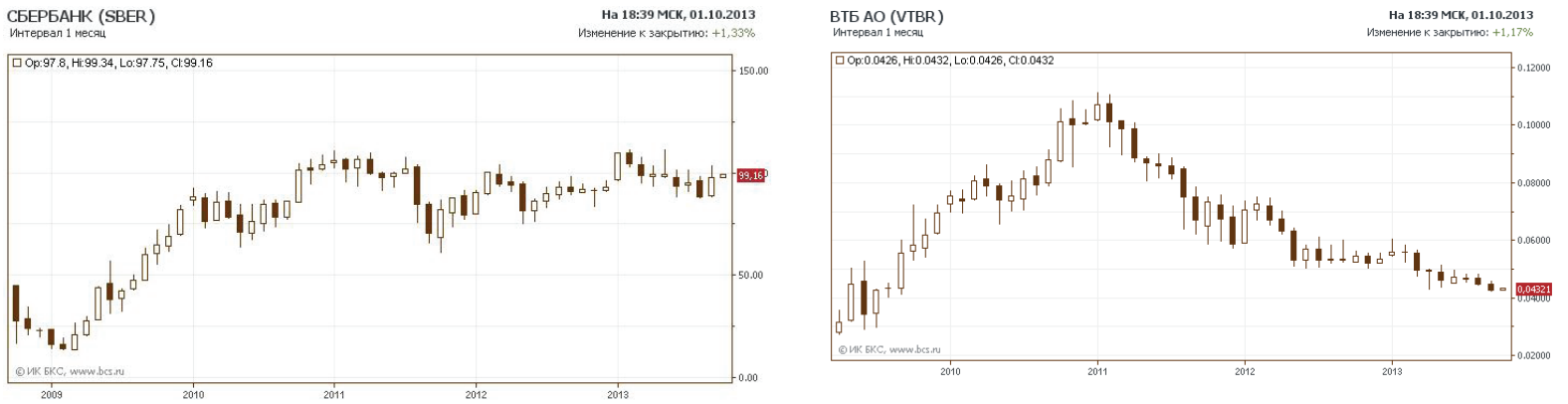

(1) Sberbank

(2) $V T B$

Source: http://bcs-express.ru

Figure 3: Market price of Sberbank and VTB in Moscow Exchange

(common stock, 2009 - October 2013) 